\title{
Physical properties of iodate solutions and the deliquescence of crystalline $\mathrm{I}_{2} \mathrm{O}_{5}$ and $\mathrm{HIO}_{3}$
}

\author{
R. Kumar ${ }^{1}$, R. W. Saunders ${ }^{1}$, A. S. Mahajan ${ }^{1, *}$, J. M.C. Plane ${ }^{1}$, and B. J. Murray ${ }^{1, * *}$ \\ ${ }^{1}$ School of Chemistry, University of Leeds, Woodhouse Lane, Leeds LS2 9JT, UK \\ *now at: Laboratory for Atmospheric and Climate Science (CIAC), CSIC, 45007 Toledo, Spain \\ ** now at: School of Earth and Environment, University of Leeds, Woodhouse Lane, Leeds LS2 9JT, UK
}

Received: 12 July 2010 - Published in Atmos. Chem. Phys. Discuss.: 1 September 2010

Revised: 3 December 2010 - Accepted: 15 December 2010 - Published: 23 December 2010

\begin{abstract}
Secondary aerosol produced from marine biogenic sources in algal-rich coastal locations will initially be composed of iodine oxide species, most likely $\mathrm{I}_{2} \mathrm{O}_{5}$, or its hydrated form $\mathrm{HIO}_{3}$, formed as a result of iodine gas-phase chemistry. At present, there is no quantitative hygroscopic data for these compounds and very little data available for iodate solutions $\left(\mathrm{HIO}_{3}\right.$ and $\mathrm{I}_{2} \mathrm{O}_{5}$ share a common aqueous phase). With increased interest in the role of such aerosol in the marine atmosphere, we have conducted studies of (i) the deliquescence behaviour of crystalline $\mathrm{HIO}_{3}$ and $\mathrm{I}_{2} \mathrm{O}_{5}$ at $273-303 \mathrm{~K}$, (ii) the efflorescence behaviour of aqueous iodate solution droplets, and (iii) properties (water activity, density, and viscosity) of subsaturated and saturated iodate solutions.

The deliquescence of $\mathrm{I}_{2} \mathrm{O}_{5}$ crystals at $293 \mathrm{~K}$ was observed to occur at a relative humidity (DRH) of $80.8 \pm 1.0 \%$, whereas for $\mathrm{HIO}_{3}$, a DRH of $85.0 \pm 1.0 \%$ was measured. These values are consistent with measured water activity values for saturated $\mathrm{I}_{2} \mathrm{O}_{5}$ and $\mathrm{HIO}_{3}$ solutions at $293 \mathrm{~K}$ of $0.80 \pm 0.01$ and $0.84 \pm 0.01$ respectively. At all temperatures, DRH values for $\mathrm{HIO}_{3}$ crystals were observed to be higher than for those of $\mathrm{I}_{2} \mathrm{O}_{5}$. The temperature-dependent DRH data, along with solubility and water activity data were used to evaluate the enthalpy of solution $\left(\Delta \mathrm{H}_{\text {sol }}\right)$ for $\mathrm{HIO}_{3}$ and $\mathrm{I}_{2} \mathrm{O}_{5}$. A $\Delta \mathrm{H}_{\text {sol }}$ value of $8.3 \pm 0.7 \mathrm{~kJ} \mathrm{~mol}^{-1}$ was determined for $\mathrm{HIO}_{3}$ which is consistent with a literature value of $8.8 \mathrm{~kJ} \mathrm{~mol}^{-1}$. For $\mathrm{I}_{2} \mathrm{O}_{5}$, we report for the first time its solubility at various temperatures and $\Delta \mathrm{H}_{\mathrm{sol}}=12.4 \pm 0.6 \mathrm{~kJ} \mathrm{~mol}^{-1}$. The measured water activity values confirm that aqueous iodate solutions are strongly non-ideal, consistent with previous reports of complex ion formation and molecular aggregation.
\end{abstract}

Correspondence to: B. J. Murray

(b.j.murray@leeds.ac.uk)

\section{Introduction}

Aerosols play an important role in many processes affecting the atmospheric chemistry and climate of the Earth (Seinfeld and Pandis, 2006). They can alter the Earth's radiative balance either directly by the scattering of solar radiation, or indirectly by acting as cloud condensation nuclei $(\mathrm{CCN})$ and ice nuclei (IN) (McFiggans et al., 2006).

For a thorough knowledge of the physical behaviour of aerosol in the atmosphere, a comprehensive understanding of critical properties (e.g. water activity $-a_{\mathrm{w}}$, density $-\rho$, and viscosity $-\eta$ ) of aqueous solutions, and deliquescence data of relevant compounds is necessary. For some inorganic compounds (primarily sodium and ammonium salts), such data has been extensively reported in the literature (Martin, 2000) and has been used in chemical-thermodynamic modelling of single component and mixed aerosol systems (Clegg et al., 1998; Wexler and Clegg, 2002; Topping et al., 2005).

The transformation from a solid crystalline phase to an aqueous solution usually occurs at a narrowly defined threshold value, known as the deliquescence relative humidity (DRH). Conversely, when RH decreases, an aqueous solution droplet first shrinks because of water evaporation and finally crystallises at a lower threshold RH (below the DRH), known as the efflorescence relative humidity (ERH) (Seinfeld and Pandis, 2006). While deliquescence is a thermodynamically controlled transition, efflorescence is kinetically controlled.

A direct link between biogenic iodine vapour release at coastal sites and aerosol formation has been firmly established through field campaigns (O'Dowd et al., 2002a; McFiggans et al., 2010) with supporting laboratory studies (e.g. O'Dowd et al., 2002b; McFiggans et al., 2004; Burkholder et al., 2004; Saunders and Plane, 2005). Whilst the speciation of iodine, primarily the ionic forms, iodate $\left(\mathrm{IO}_{3}^{-}\right)$and iodide $\left(\mathrm{I}^{-}\right)$, within marine aerosol has been discussed (Pechtl et al.,

Published by Copernicus Publications on behalf of the European Geosciences Union. 
2007; Gilfedder et al., 2008), the relatively recent cited studies of coastal secondary particle formation involving iodine oxides (see the review of O'Dowd and De Leeuw, 2007), with the possibility of such aerosol also being important in open-ocean and polar environments (Mahajan et al., 2010; Saiz-Lopez et al., 2007), has necessitated a greater understanding of the solid-phase species $\mathrm{I}_{2} \mathrm{O}_{4}, \mathrm{I}_{2} \mathrm{O}_{5}$ and $\mathrm{HIO}_{3}$, as well as their aqueous phases.

In this study we focus on $\mathrm{I}_{2} \mathrm{O}_{5}$ and $\mathrm{HIO}_{3}$ as $\mathrm{I}_{2} \mathrm{O}_{5}$ composition has been directly identified in laboratory-generated iodine oxide particles (referred to henceforth as IOPs) formed in a 'dry' (low RH) environment (Saunders and Plane, 2005; Saunders et al., 2010). On a practical level, it is not possible to study the solution properties of $\mathrm{I}_{2} \mathrm{O}_{4}$ as this solid slowly disproportionates into $\mathrm{I}_{2}(\mathrm{aq} / \mathrm{s})$ and $\mathrm{HIO}_{3}(\mathrm{aq})$ in water (Daehlie and Kjekshus, 1964). More important however, is that to date, the non-hygroscopic tetra-oxide has only been indirectly inferred for IOP composition from a lack of observed hygroscopic growth exhibited by particles (Jimenez et al., 2003) - we will discuss this issue later in the paper (see Conclusions and atmospheric implications).

Dissolution of the crystalline solids $\mathrm{I}_{2} \mathrm{O}_{5}$ and $\mathrm{HIO}_{3}$ leads to a common iodate $\left(\mathrm{IO}_{3}^{-}\right)$aqueous phase;

$$
\begin{aligned}
& \mathrm{I}_{2} \mathrm{O}_{5}(s)+\mathrm{H}_{2} \mathrm{O} \rightarrow 2 \mathrm{HIO}_{3}(a q) \rightarrow 2\left(\mathrm{H}^{+}+\mathrm{IO}_{3}^{-}\right)(a q) \\
& \mathrm{HIO}_{3}(s)+\mathrm{H}_{2} \mathrm{O} \rightarrow \mathrm{H}^{+}(a q)+\mathrm{IO}_{3}^{-}(a q)
\end{aligned}
$$

Hence, while it is expected that the crystals will have different physical properties, their aqueous solutions will be identical. In this paper we express the concentration of solutions made with both solids as the formal molality of iodate $\left[m\left(\mathrm{IO}_{3}^{-}\right)\right]$. For $\mathrm{HIO}_{3}, m\left(\mathrm{IO}_{3}^{-}\right)$is simply $m\left(\mathrm{HIO}_{3}\right)$ while for $\mathrm{I}_{2} \mathrm{O}_{5}$ we can state:

$m\left(\mathrm{IO}_{3}^{-}\right)$

$=m\left(\mathrm{I}_{2} \mathrm{O}_{5}\right) \times\left[\frac{\text { moles of } \mathrm{H}_{2} \mathrm{O}}{\text { moles of } \mathrm{H}_{2} \mathrm{O}-\text { moles of } \mathrm{I}_{2} \mathrm{O}_{5}}\right] \times 2$

where $m\left(\mathrm{I}_{2} \mathrm{O}_{5}\right)$ is the solution molality of $\mathrm{I}_{2} \mathrm{O}_{5}$.

Appropriate physical data for $\mathrm{I}_{2} \mathrm{O}_{5}$ and $\mathrm{HIO}_{3}$ is sparse in the literature. Some iodate solution properties are reported in studies which date back over more than a century (Groschuff, 1905; Nayar et al., 1939; Goldman et al., 1974; Strong and Pethybridge, 1987), but there is a lack of sufficiently detailed data available and therefore an assessment of the potential climatic impact of these aerosol-forming compounds is currently not possible.

In this study, our motivation was to provide the underpinning physical knowledge required to improve the understanding of solid and aqueous phase iodine oxide particles. This study is focused on the deliquescence behaviour of $\mathrm{I}_{2} \mathrm{O}_{5}$ and $\mathrm{HIO}_{3}$ crystals in addition to various physical properties (water activity, density and viscosity) of aqueous iodate solutions. We also report our attempt to study the efflorescence of iodate solutions at low relative humidity.

\section{Experimental}

\subsection{Water activity measurements}

A number of iodate solutions were prepared from crystalline $\mathrm{I}_{2} \mathrm{O}_{5}$ and $\mathrm{HIO}_{3}\left(\mathrm{I}_{2} \mathrm{O}_{5}: 99.99 \%\right.$, Sigma-Aldrich and $\mathrm{HIO}_{3}$ : $\geq 99.5 \%$, Sigma-Aldrich) in $18.2 \mathrm{M} \Omega$ ultra-pure water, spanning a molality $(\mathrm{m})$ range up to and including that of a saturated solution of $\left.\mathrm{HIO}_{3}(m=17.3 \text { moles kg})^{-1} / 75.3 \mathrm{wt} \%\right)$ and of $\mathrm{I}_{2} \mathrm{O}_{5}\left(m=7.8\right.$ moles kg $\left.{ }^{-1} / 72.2 \mathrm{wt} \%\right)$ at $293 \mathrm{~K}$.

Water activities $\left[a_{\mathrm{w}}(T)=p(T) / p^{o}(T)\right.$; where $p(T)$ is the equilibrium vapour pressure above a solution surface at temperature $T$ and $p^{o}(T)$ is the vapour pressure above pure water at the same temperature] of aqueous solutions were measured directly using an automated activity meter (Aqualab series 3TE, Decagon Devices Inc.; accuracy \pm 0.003 ). The instrument utilizes the chilled mirror dew-point technique to determine the dew point of air in equilibrium with a solution. The instrument was calibrated before each $\mathrm{I}_{2} \mathrm{O}_{5}$ and $\mathrm{HIO}_{3}$ solution measurement using both pure water $\left(a_{\mathrm{w}}=1\right)$ and an aqueous solution of $\mathrm{LiCl}\left(13.41 m, a_{\mathrm{w}}=0.25\right)$ (Stoloff, 1978).

\subsection{Density measurements}

The densities of a series of $\mathrm{I}_{2} \mathrm{O}_{5}$ and $\mathrm{HIO}_{3}$ solutions were measured at $293 \mathrm{~K}$. All solutions were carefully prepared in volumetric flasks by dissolving the respective solids in $18.2 \mathrm{M} \Omega$ ultra pure water and densities were determined by gravimetric analysis using a precision weighing balance (accuracy of $0.1 \mathrm{mg}$ ).

\subsection{Viscosity measurements}

The viscosities of the high molality $(15.8<$ $m\left(\mathrm{IO}_{3}^{-}\right) \leq 17.6$ moles $\left.\mathrm{kg}^{-1}\right) \quad$ solutions were measured over the temperature range of $293-303 \mathrm{~K}$ using a falling ball viscometer (Gilmont GV-2300, size-3). Approximately $7 \mathrm{ml}$ of each solution were placed into the tube of the viscometer which was immersed in a large beaker of water, placed onto a heating/magnetic stirring plate. The water was heated to the desired temperature (measured with a K-type thermocouple) and stirred continuously. The viscometer was then left for $\sim 30 \mathrm{~min}$ to equilibrate with the water temperature. The descent times of the ball in each solution were then measured a number of times (typically 10 for each solution and temperature) and the average time was used to determine the dynamic viscosity $\left(\eta / \mathrm{cP}\right.$; where $\left.1 \mathrm{cP} \equiv 10^{-3} \mathrm{Pas}\right)$ of the solution from the formula:

$\eta=K\left(\rho_{t}-\rho\right) t$

Where, $\rho_{t}$ is the density of the ball $\left(\mathrm{g} \mathrm{cm}^{-3}\right), \rho$ is the density of liquid $\left(\mathrm{g} \mathrm{cm}^{-3}\right), t$ is the time of descent (minutes) and $\mathrm{K}$ is the viscometer constant (for the size- 3 viscometer, the value of $\mathrm{K}$ is 35 ). 


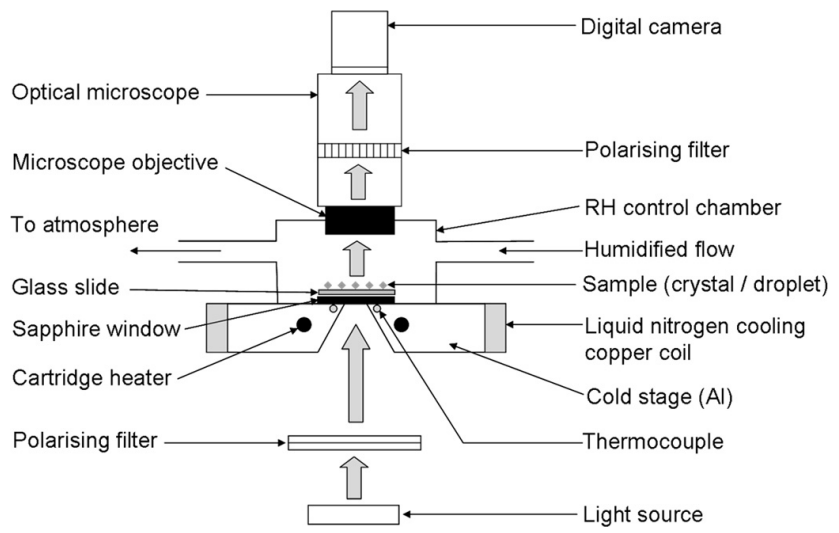

Fig. 1. Schematic depiction of the experimental set-up used to study the deliquescence of crystalline particles and the efflorescence of aqueous solution droplets.

A 99\% glycerol solution (Aldrich) was used initially to verify the performance of the viscometer. Measured solution viscosities at a number of temperatures were found to agree to within $5 \%$ of those reported in the literature (Segur and Oberstar, 1951).

\subsection{Deliquescence and efflorescence measurements}

Deliquescence and efflorescence behaviour of $\mathrm{I}_{2} \mathrm{O}_{5}$ and $\mathrm{HIO}_{3}$ crystals/droplets were studied using an optical microscope (Olympus BX51) coupled to a home-made temperature and humidity controlled stage (Murray et al., 2010a, b). A schematic diagram of this equipment is shown in Fig. 1.

The water vapour pressure in the $\mathrm{N}_{2}$ gas flow through the chamber was controlled by passing the gas through a liquid water bubbler and a trap which were immersed in a coolant mixture (50:50 ethylene glycol and water) in a temperature controlled bath (Haake K40). The bubbler served to humidify the flow and the trap (a glass bubbler with only condensation on its walls) served to remove extra water vapour resulting from aerosol formation associated with bubble bursting in the bubbler. The water vapour pressure passing into the cell could therefore be controlled by changing the temperature of the bath between $0{ }^{\circ} \mathrm{C}$ and room temperature and for lower dew points the flow was diluted with dry $\mathrm{N}_{2}$. The humidified and dry flows were quantified using mass flow controllers (MKS 1179). The temperature of the bubbler and trap were recorded using a calibrated thermocouple.

The temperature of the stage was set using a temperature controller (Eurotherm 2416) and heaters $(2 \times 35 \mathrm{~W})$ embedded in the cold stage which was cooled with a constant flow of cold gas from a pressurised liquid nitrogen dewar. The relative humidity around the droplet/particles in the chamber is the ratio of the partial pressure of water in the gas phase, defined by the bubbler temperature, to the equilibrium vapour pressure of water at the temperature of the stage. The temperature dependent parameterisation for the equilibrium vapour
Table 1. Polynomial coefficients for fits (see equations at the foot of the table) to measured water activity $\left(a_{\mathrm{W}}\right)$ and solution density $(\rho)$ data (see Figs. 2 and 3 respectively) for iodate solutions at $293 \mathrm{~K}$. Concentrations are expressed as the molality of $\mathrm{IO}_{3}^{-}\left[m\left(\mathrm{IO}_{3}^{-}\right)\right]$.

\begin{tabular}{llll}
\hline \multicolumn{2}{c}{ Coefficients of water activity, $a_{\mathrm{w}}^{\mathrm{a}}$} & \multicolumn{2}{c}{ Coefficients of density, $\rho / \mathrm{g} \mathrm{cm}^{-3 \mathrm{~b}}$} \\
\hline $\mathrm{A}_{1}$ & -1.21 & $\mathrm{~B}_{1}$ & 3.05 \\
& $\times 10^{-3}$ & & $\times 10^{-2}$ \\
$\mathrm{~A}_{2}$ & 5.73 & $\mathrm{~B}_{2}$ & 2.03 \\
& $\times 10^{-4}$ & & $\times 10^{-2}$ \\
$\mathrm{~A}_{3}$ & -2.19 & $\mathrm{~B}_{3}$ & -2.41 \\
& $\times 10^{-4}$ & & $\times 10^{-3}$ \\
$\mathrm{~A}_{4}$ & 2.07 & $\mathrm{~B}_{4}$ & 8.12 \\
& $\times 10^{-5}$ & & $\times 10^{-5}$ \\
$\mathrm{~A}_{5}$ & -6.65 & $\mathrm{~B}_{5}$ & 1.35 \\
& $\times 10^{-7}$ & & $\times 10^{-8}$ \\
\hline
\end{tabular}

a $a_{w}=1+\Sigma_{i=1-5}\left(A_{i} \times m^{i}\right)$

$\mathrm{b}_{\rho}=0.997+\Sigma_{i=1-5}\left(B_{i} \times m^{i}\right)$

pressure of water was taken from the literature (Murphy and Koop, 2005).

Deliquescence: Crystals of $\mathrm{I}_{2} \mathrm{O}_{5}$ and $\mathrm{HIO}_{3}$ (typical sizes of $10-50 \mu \mathrm{m}$ ) were placed onto a hydrophobic glass slide which had been pre-cleaned in Piranha solution $\left(\mathrm{H}_{2} \mathrm{SO}_{4}: \mathrm{H}_{2} \mathrm{O}_{2}\right.$ mixture), rinsed with $18.2 \mathrm{M} \Omega$ water and methanol, and then silanised using a $5 \%$ solution of dichlorodimethylsilane in heptane. Aqueous droplets supported on surfaces prepared in this manner have a contact angle of $\sim 100^{\circ}$ and do not induce phase changes (Murray et al., 2010a, b; Dymarska et al., 2006; Eastwood et al., 2009). The slide was then placed on the cold stage of the instrument under the optical microscope which was connected to a grey-scale digital camera (Hitachi). Images were viewed on a monitor and recorded digitally using a commercial DVD recorder. Relative humidity and temperature data were logged during the course of an experiment.

Efflorescence: Aqueous droplets formed in the deliquescence experiments were subsequently exposed to decreasing $\mathrm{RH}$ down to $\sim 0 \% \mathrm{RH}$ while monitoring the microscope images for evidence of crystallisation.

The deliquescence/efflorescence set-up was initially tested using ammonium sulphate crystals ( $>99.0 \%$, Aldrich), and gave very good agreement (to within $\pm 1 \%$, our uncertainty in $\mathrm{RH}$ ) with values reported in a number of laboratory studies e.g. a DRH of $80 \pm 1 \%$ and ERH of $32 \pm 1 \%$ at $298 \mathrm{~K}$ (Tang and Munkelwitz, 1993; Onasch et al., 1999) and those calculated using the AIM aerosol thermodynamics model (e.g. Clegg et al., 1998). 


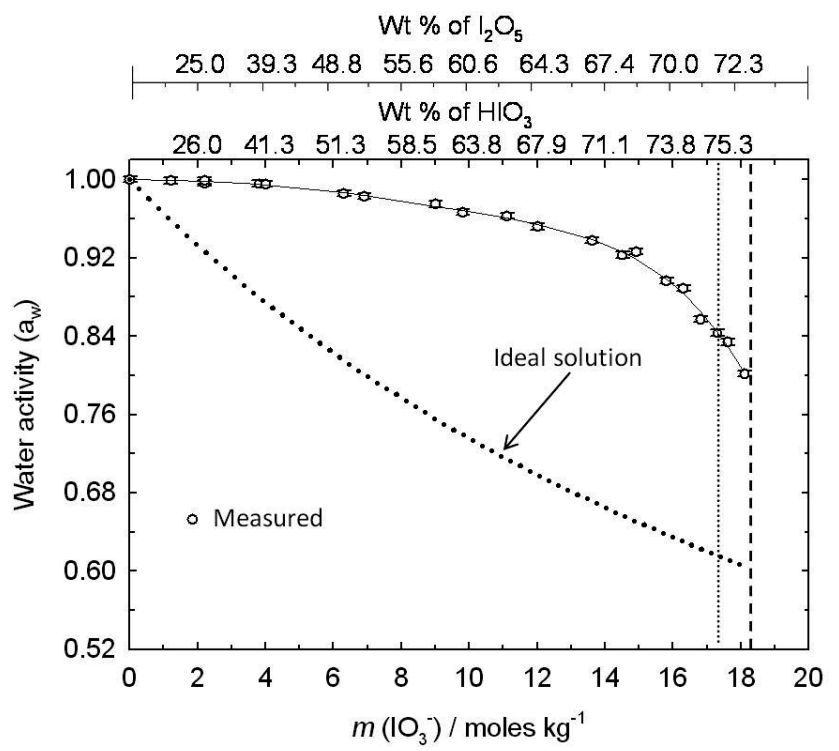

Fig. 2. Measured water activity values (open circles) at $293 \mathrm{~K}$ for aqueous solutions of $\mathrm{IO}_{3}^{-}$from $\mathrm{HIO}_{3} / \mathrm{I}_{2} \mathrm{O}_{5}$ over a range of molalities up to, and including that of a saturated solution of each solid. The solid line is a fifth order polynomial best-fit to the data (see Table 1). The vertical dashed line indicates the saturation molality for $\mathrm{I}_{2} \mathrm{O}_{5}$ and dotted line indicates the saturation molality for $\mathrm{HIO}_{3}$ (or wt $\%$ - see top axis). The ideal water activity values (assuming full dissociation into ions) are indicated by the square dotted line.

Table 2. Fitted Arrhenius parameters for the temperature dependent viscosity data (see Fig. 5).

\begin{tabular}{lll}
\hline $\begin{array}{l}m\left(\mathrm{IO}_{3}^{-}\right) / \\
\text {moles kg }\end{array}$ & $\begin{array}{l}\text { Viscosity } \\
\text { coefficient }(\mathrm{A}) / \mathrm{cP}\end{array}$ & $\begin{array}{l}\text { Activation energy } \\
(\mathrm{Ea}) / \mathrm{kJ} \mathrm{mol}^{-1}\end{array}$ \\
\hline 17.6 & $1.94 \pm 0.03 \times 10^{-7}$ & $50.4 \pm 1.2$ \\
17.3 & $4.57 \pm 0.06 \times 10^{-7}$ & $47.7 \pm 2.3$ \\
16.8 & $9.38 \pm 0.06 \times 10^{-7}$ & $45.1 \pm 1.9$ \\
15.8 & $1.07 \pm 0.08 \times 10^{-6}$ & $42.2 \pm 2.9$ \\
\hline
\end{tabular}

\section{Results and discussion}

\subsection{Water activity measurements}

The measured water activity $\left(a_{\mathrm{w}}\right)$ at $293 \mathrm{~K}$ for solutions with a range of iodate concentrations made up with $\mathrm{I}_{2} \mathrm{O}_{5}$ and $\mathrm{HIO}_{3}$ are plotted in Fig. 2.

The data points shown at highest molality correspond to the water activities of iodate solutions for saturated solutions of $\mathrm{I}_{2} \mathrm{O}_{5}$ (we used our measurement of solubility derived later in this paper rather than the value given in the CRC handbook; Lide, 2009). The plotted data was fitted using a fifth order polynomial function for which the coefficient values and functional form are shown in Table 1.

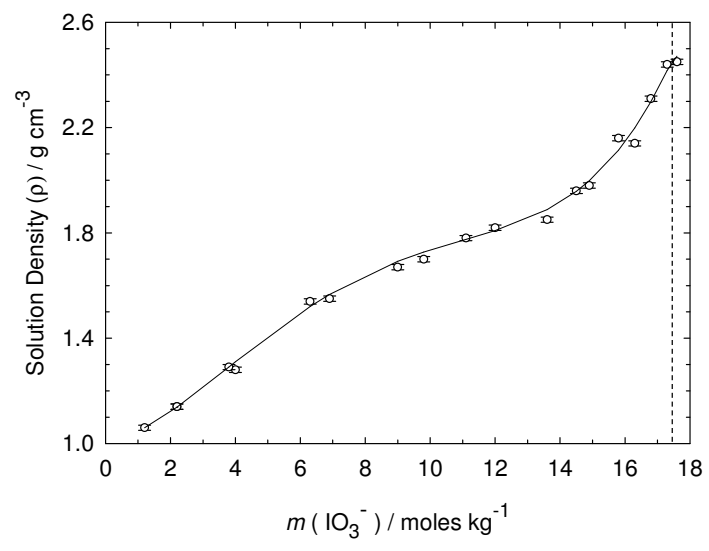

Fig. 3. Measured iodate solution densities at $293 \mathrm{~K}$ as a function of $m\left(\mathrm{IO}_{3}^{-}\right)$over a range of molalities up to and including that of a saturated solution of $\mathrm{HIO}_{3}$. The solid line is a polynomial bestfit to the data (see Table 1). The vertical dashed line indicates the saturation molality of $\mathrm{HIO}_{3}$.

It can be seen from Fig. 2 that the water activity decreases steadily with increasing molality as expected. However, the data shows a positive deviation from ideality [assuming full dissociation of both compounds into the respective ions in solution and that $a_{\mathrm{w}}=v_{\mathrm{H}_{2} \mathrm{O}} /\left(v_{\mathrm{H}_{2} \mathrm{O}}+v_{\text {ions }}\right)$, where $v$ is the number of moles (Sereno et al., 2001; Caurie, 1983)] at all $m$ values up to $\mathrm{I}_{2} \mathrm{O}_{5}$ saturation where $a_{\mathrm{w}}$ (ideal) $=0.60 \mathrm{com}$ pared with the measured value of $0.80 \pm 0.01$. This positive deviation is consistent with the complex solution structures previously reported from conductance measurements (Pethybridge and Prue, 1967), which identified the ionic species, $\mathrm{H}\left(\mathrm{IO}_{3}\right)_{2}^{-}$(from association of $\mathrm{HIO}_{3}+\mathrm{IO}_{3}^{-}$) in dilute solutions, and by Goldman et al. (1974) who identified an increasing degree of molecular association $\left(\mathrm{HIO}_{3}\right.$ dimers, trimers and tetramers) at higher concentrations.

\subsection{Density measurements}

The measured density data at $293 \mathrm{~K}$ is shown in Fig. 3 for a number of $\mathrm{HIO}_{3}$ and $\mathrm{I}_{2} \mathrm{O}_{5}$ solutions up to saturation, as a function of $m\left(\mathrm{IO}_{3}^{-}\right)$. A fifth order polynomial function was used to fit the density data - see Table 1 for the function and coefficients.

\subsection{Viscosity measurements}

Measured viscosity data for $15.8, \leq m\left(\mathrm{IO}_{3}^{-}\right) \leq 17.6$ moles $\mathrm{kg}^{-1}$ at $303 \mathrm{~K}$ for aqueous solutions are plotted in Fig. 4 as a function of $m\left(\mathrm{IO}_{3}^{-}\right)$, along with the data reported by Nayar et al. (1939) for $m \leq 4$ moles kg-1. Fig. 4 shows a rapidly increasing solution viscosity at higher concentrations (with $\eta=97 \pm 1 \mathrm{cP}$ at saturation i.e. $\sim 2$ orders of magnitude greater than $\eta_{\text {water }}$ at $303 \mathrm{~K}$ i.e. $\sim 0.8 \mathrm{cP}$, Korson et al., 1969), for which a best fit exponential function is given in the figure caption. At lower temperature, for 


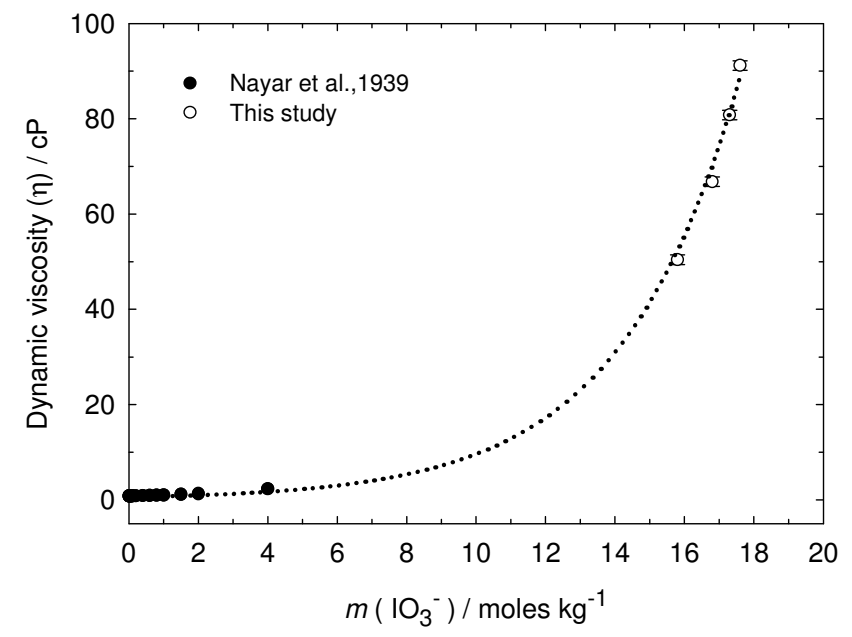

Fig. 4. Measured (open circles) and literature (filled circles) viscosity data for aqueous iodate solutions at $303 \mathrm{~K}$, as a function of $m\left(\mathrm{IO}_{3}^{-}\right)$. Our data is shown in addition to data from the literature (Nayar et al., 1939). The dotted line is a least-squares exponential fit $(\eta[\mathrm{cP}]=0.798 \exp \{0.267 \times m\})$ through all data points.

an equivalent solution molality, higher viscosities were observed. The data measured at 293, 298 and $303 \mathrm{~K}$ for solutions of $15.8 \leq m\left(\mathrm{IO}_{3}^{-}\right) \leq 17.6$ moles kg ${ }^{-1}$ are shown in an Arrhenius plot in Fig. 5.

From this figure, the viscosity trends of these concentrated solutions are consistent with first order fluid behaviour i.e. exponentially decreasing viscosity with increasing temperature for all $m$ (see Table 2 for fitted parameters). While the temperature dependence of viscosity of these solutions approximates well to an Arrhenius law, it is well known that the Arrhenius law under-predicts the temperature dependence of many aqueous solutions (Angell, 2002; Murray, 2008b). Hence, extrapolation of the fit to lower temperatures only provides a lower limit to viscosity. Bearing this in mind, for a saturated solution the fit yields a viscosity of $5054 \mathrm{cP}$ at $253 \mathrm{~K}$ - a temperature relevant for marine polar regions. This suggests iodate solution droplets become very viscous under atmospherically relevant conditions and this may have important implications for their growth through uptake of other condensable vapours. More concentrated solutions would be even more viscous. Implications of this are discussed in more detail later.

\subsection{Deliquescence and efflorescence behaviour}

\subsubsection{Deliquescence}

Figure 6 shows a sequence of recorded images from an $\mathrm{I}_{2} \mathrm{O}_{5}$ deliquescence experiment at $T=298 \mathrm{~K}$. The RH was increased across the deliquescence point in increments of $0.5 \%$ and the droplets left for $5 \mathrm{~min}$ at each increment.

Panel (i) shows solid crystals on the sample slide under dry $\mathrm{N}_{2}$ gas; (ii) shows that at $\mathrm{RH}=78.8 \pm 1.0 \%$, which

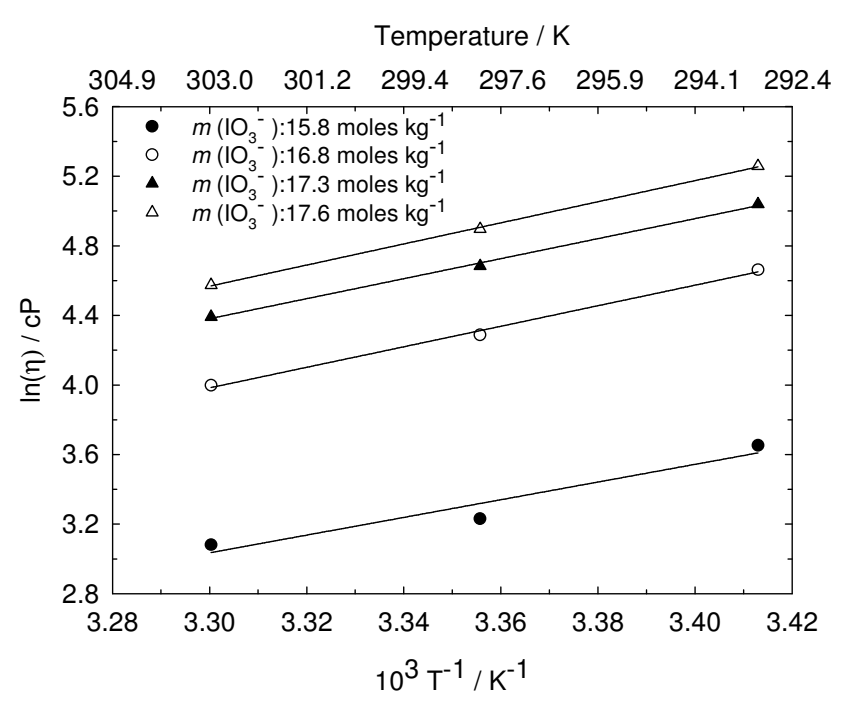

Fig. 5. Measured viscosity data for aqueous iodate solutions as a function of temperature, and associated linear fits (solid lines) using an Arrhenius equation of the form, $\ln (\eta)=\ln A+\left(E_{\mathrm{a}} / R T\right)-$ see Table 2 for fitted values of $A$, (the pre-exponential viscosity coefficient), and $E_{\mathrm{a}}$, (the activation energy).

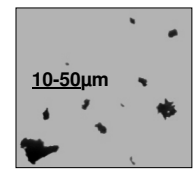

(i) $\mathrm{RH}<1 \%$

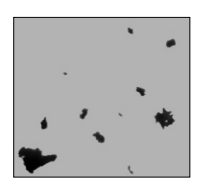

(ii) $\mathrm{RH}=78.8 \pm 1.0 \%$ (iii) $\mathrm{RH}=79.5 \pm 1.0 \%$ (iv) $\mathrm{RH}=80.0 \pm 1.0 \%$
Fig. 6. A series of microscope images of $\mathrm{I}_{2} \mathrm{O}_{5}$ crystals at $298 \mathrm{~K}$ : (i) at low RH, (ii) just below the deliquescence point and (iii) at the point of deliquescence, and (iv) shows aqueous solution droplets.

is just below the deliquescence $\mathrm{RH}$, the crystals are unchanged; (iii) shows crystals beginning to take up water at $\mathrm{RH}=79.5 \pm 1.0 \%$, whilst panel (iv) shows fully deliquesced aqueous droplets at $\mathrm{RH}=80.0 \pm 1.0 \%$. From these images we determine the DRH of $\mathrm{I}_{2} \mathrm{O}_{5}$ at $298 \mathrm{~K}$ as $79.5 \pm 1.0 \%$. These experiments were repeated for a range of temperatures for both $\mathrm{HIO}_{3}$ and $\mathrm{I}_{2} \mathrm{O}_{5}$ (from $273-303 \mathrm{~K}$ ). The results are given in Table 3.

The DRH values of $\mathrm{HIO}_{3}(85.0 \pm 1.0 \%)$ and $\mathrm{I}_{2} \mathrm{O}_{5}$ $(80.8 \pm 1.0 \%)$ at $293 \mathrm{~K}$ are in good agreement with the measured water activity $\left(\% \mathrm{DRH}=a_{w}\right.$ of a saturated solution $\times 100$, when the aqueous droplet is in equilibrium with water vapour) for saturated solutions $\left(a_{\mathrm{w}}=0.84 \pm 0.01\right.$ for $\mathrm{HIO}_{3}$ and $a_{\mathrm{w}}=0.80 \pm 0.01$ for $\mathrm{I}_{2} \mathrm{O}_{5}$ ) at this temperature (see Fig. 2).

Differences in the crystalline structures and chemical potential of $\mathrm{HIO}_{3}$ and $\mathrm{I}_{2} \mathrm{O}_{5}$ (Rogers, 1941; Selte and Kjekshus, 1970) are reflected in the differing DRH values for each compound. Although these two solids form identical aqueous solutions, they will have different enthalpies of solution $\left(\Delta \mathrm{H}_{\mathrm{sol}}\right)$. This parameter can be derived from temperature-dependent DRH 
Table 3. Measured values of deliquescence relative humidity (DRH) for $\mathrm{I}_{2} \mathrm{O}_{5}$ and $\mathrm{HIO}_{3}$ crystals from $273-303 \mathrm{~K}$.

\begin{tabular}{lll}
\hline Temperature/K & $\begin{array}{l}\mathrm{DRH}[\%]-\mathrm{I}_{2} \mathrm{O}_{5}, \\
\pm 1 \%\end{array}$ & $\begin{array}{l}\mathrm{DRH}[\%]-\mathrm{HIO}_{3}, \\
\pm 1 \%\end{array}$ \\
\hline 273 & 84.5 & 90.9 \\
278 & 83.3 & 89.4 \\
283 & 82.7 & 87.4 \\
288 & 81.2 & 86.7 \\
293 & 80.8 & 85.0 \\
298 & 79.5 & 83.5 \\
303 & 78.3 & 81.1 \\
\hline
\end{tabular}

Table 4. Calculated aqueous solubility of $\mathrm{I}_{2} \mathrm{O}_{5}$ from $273-303 \mathrm{~K}$. These values are derived from our water activity and deliquescence measurements (see text).

\begin{tabular}{ll}
\hline Temperature/K & $\begin{array}{l}\text { Solubility of } \mathrm{I}_{2} \mathrm{O}_{5} / \mathrm{g} \text { per } 100 \mathrm{~g} \text { of } \mathrm{H}_{2} \mathrm{O} \\
\text { Accuracy } \pm 3.5 \mathrm{~g} \text { per } 100 \mathrm{~g} \text { of } \mathrm{H}_{2} \mathrm{O}\end{array}$ \\
\hline 273 & 244.1 \\
278 & 246.6 \\
283 & 249.7 \\
288 & 253.5 \\
293 & 258.0 \\
298 & 263.2 \\
303 & 269.0 \\
\hline
\end{tabular}

measurements following the method outlined by Tang and Munkelwitz (1993), if temperature-dependent solubility data is available for the solid in question. Such data does not exist in the literature for $\mathrm{I}_{2} \mathrm{O}_{5}$, but is known for $\mathrm{HIO}_{3}$ over the range $273-373 \mathrm{~K}$ (Lide, 2009).

The enthalpy of solution can be evaluated by applying the Clausius-Clapeyron equation for the phase transformation, as given by,

$\frac{d \ln a_{\mathrm{w}}}{d T}=-\frac{n \Delta H_{\mathrm{sol}}}{R T^{2}}$

where $R$ is the gas constant, and $a_{\mathrm{w}}$ is defined as:

$a_{\mathrm{w}}=\frac{p}{p^{o}}=\frac{\% \mathrm{DRH}}{100}$

The solubility $(n)$ in moles of solute per moles of water can be expressed as a quadratic function of $T$ :

$n=\mathrm{A}+\mathrm{B} T+\mathrm{C} T^{2}$

The values of the coefficients A, B, and C can therefore be calculated from a fit of solubility data at different temperatures. For $\mathrm{HIO}_{3}$ the fitted coefficient values are as follows: $\mathrm{A}=1.998, \mathrm{~B}=-1.310 \times 10^{-2}, \mathrm{C}=2.500 \times 10^{-5}$.

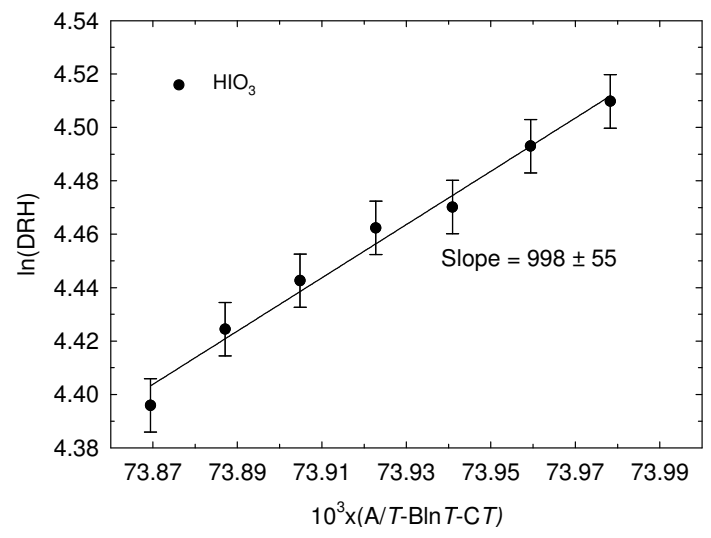

Fig. 7. A plot of measured deliquescence $\mathrm{RH}$ values for $\mathrm{HIO}_{3}$ against the temperature function which includes fitted solubility data (see Sect. 3.4).

We first derived temperature dependent solubility values for $\mathrm{I}_{2} \mathrm{O}_{5}$ using our measurements of water activity and temperature dependent deliquescence $\mathrm{RH}$ values. The deliquescence point is the RH at which a crystal is in equilibrium with a saturated solution. Since the water activity of a saturated solution is equal to the RH, the DRH is equal to the water activity of a saturated solution. We therefore used our measured relationship between water activity and molality to determine the molality of a saturated solution. In order to do this we assume that water activity is independent of temperature, which is a good approximation for many aqueous solutions (Koop, 2004; Kitic et al., 1986). The calculated aqueous solubility at a number of temperatures for $\mathrm{I}_{2} \mathrm{O}_{5}$ is given in Table 4.

Fitting Eq. (5) to this data yields the following solubility coefficients: $\mathrm{A}=6.124 \times 10^{-1}, \mathrm{~B}=-3.751 \times 10^{-3}$, $\mathrm{C}=7.289 \times 10^{-6}$. The $\mathrm{CRC}$ handbook gives a value of $253.4 \mathrm{~g} / 100 \mathrm{~g}$ water at $293 \mathrm{~K}$, whereas we find a value of $258.0 \pm 3.5 \mathrm{~g} / 100 \mathrm{~g}$ water at the same temperature.

For verification of this method of determining solubility, the solubility of $\mathrm{HIO}_{3}$ at various temperatures was calculated using the measured DRH and $a_{\mathrm{w}}$ values. The calculated values of solubility were found to be in good agreement with the data given in the CRC Handbook (Lide, 2009).

For calculation of the enthalpy of solution $\left(\Delta \mathrm{H}_{\mathrm{sol}}\right)$, the expressions for $n$ from Eq. (5) and DRH from Eq. (4) were substituted into Eq. (3), and on integrating the resulting equation with respect to $T$, we find;

$\operatorname{lnDRH}=\frac{\Delta H_{\text {sol }}}{R}\left[\frac{\mathrm{A}}{T}-\mathrm{B} \ln T-\mathrm{C} T\right]+I$

where $I$ is the integration constant.

Equation (6) therefore predicts a linear fit when values of $\ln (\mathrm{DRH})$ are plotted against the function $(\mathrm{A} / T-\mathrm{B} \ln T-\mathrm{C} T)$ with a slope of $\Delta H_{\mathrm{sol}} / R$. Figures 7 and 8 show such plots for the $\mathrm{HIO}_{3}$ and $\mathrm{I}_{2} \mathrm{O}_{5}$ data respectively. The calculated value of 


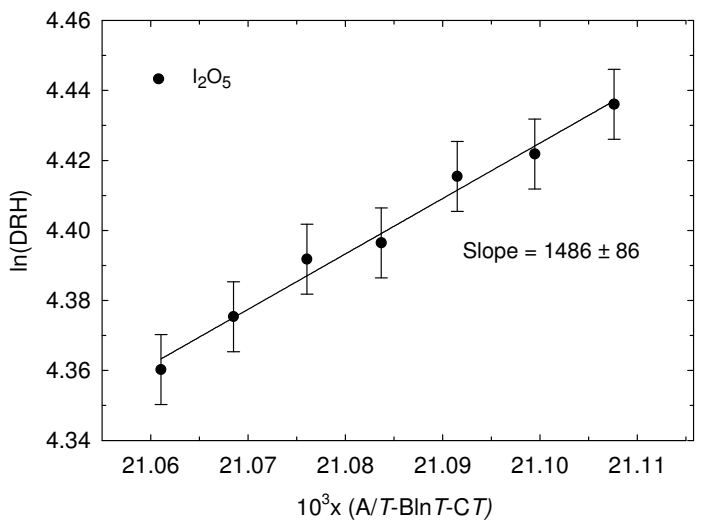

Fig. 8. A plot of measured deliquescence $\mathrm{RH}$ values for $\mathrm{I}_{2} \mathrm{O}_{5}$ against the temperature function which includes calculated solubility data (see Sect. 3.4).

$\Delta \mathrm{H}_{\text {sol }}$ from the fitted data in Fig. 7 of $8.3 \pm 0.7 \mathrm{~kJ} \mathrm{~mol}^{-1}$ is consistent with the value quoted in the CRC Handbook of + $8.8 \mathrm{~kJ} \mathrm{~mol}^{-1}$. For $\mathrm{I}_{2} \mathrm{O}_{5}$, the calculated value of $\Delta \mathrm{H}_{\text {sol }}$ from the slope of the fit shown in Fig. 8 is $12.4 \pm 0.6 \mathrm{~kJ} \mathrm{~mol}^{-1}$. This represents the first determination of this quantity that we are aware of.

As a test for the procedure described above, the measured DRH variation for ammonium sulphate (Sect. 2.4) was used along with solubility data from the literature (Tang and Munkelwitz, 1993) to fit the enthalpy of solution for this compound. The calculated value for $\Delta \mathrm{H}_{\mathrm{sol}}$ of $5.9 \pm 0.5 \mathrm{~kJ} \mathrm{~mol}^{-1}$ is in good agreement with the literature value of $+6.3 \mathrm{~kJ} \mathrm{~mol}^{-1}$.

Finally, the solubility coefficients A, B and C and evaluated $\Delta \mathrm{H}_{\text {sol }}$ were implemented in the defining equation linking the theoretical DRH (\%) variation with temperature (Tang and Munkelwitz, 1993);

$\operatorname{DRH}(T)=\operatorname{DRH}\left(T_{o}\right) \exp \left[\frac{\Delta H_{\text {sol }}}{R}\left\{A\left(\frac{1}{T}-\frac{1}{T_{o}}\right)-B \ln \left(\frac{T}{T_{o}}\right)-C\left(T-T_{o}\right)\right\}\right]$

Where $T_{o}$ is a reference temperature and $\mathrm{DRH}\left(T_{o}\right)$ is the reference value of DRH at this temperature. In our experiments, $T_{o}$ is taken at $293 \mathrm{~K}$ and the measured water activity of a saturated solution of $\mathrm{HIO}_{3}$ and $\mathrm{I}_{2} \mathrm{O}_{5}$ at this temperature was used to evaluate DRH $\left(T_{o}\right)$. Measured deliquescence data for $\left(\mathrm{NH}_{4}\right)_{2} \mathrm{SO}_{4}, \mathrm{HIO}_{3}$, and $\mathrm{I}_{2} \mathrm{O}_{5}$ crystals at $273<T<303 \mathrm{~K}$ and the corresponding theoretical lines based on Eq. (7) are shown in Fig. 9.

The DRH values determined using Eq. (7) for $\mathrm{HIO}_{3}$ and $\mathrm{I}_{2} \mathrm{O}_{5}$ were extrapolated to $250 \mathrm{~K}$ in Fig. 10 in order to estimate values applicable to a variety of marine locations (temperate to polar). From this figure, the expected DRH values of $\mathrm{HIO}_{3}$ and $\mathrm{I}_{2} \mathrm{O}_{5}$ at $253 \mathrm{~K}$ are determined at $97.2 \pm 1.0 \%$ and $88.5 \pm 1.0 \%$ respectively. However, under these conditions the atmosphere is supersaturated with respect to ice. If IOPs are initially crystalline, they may either deliquesce at high

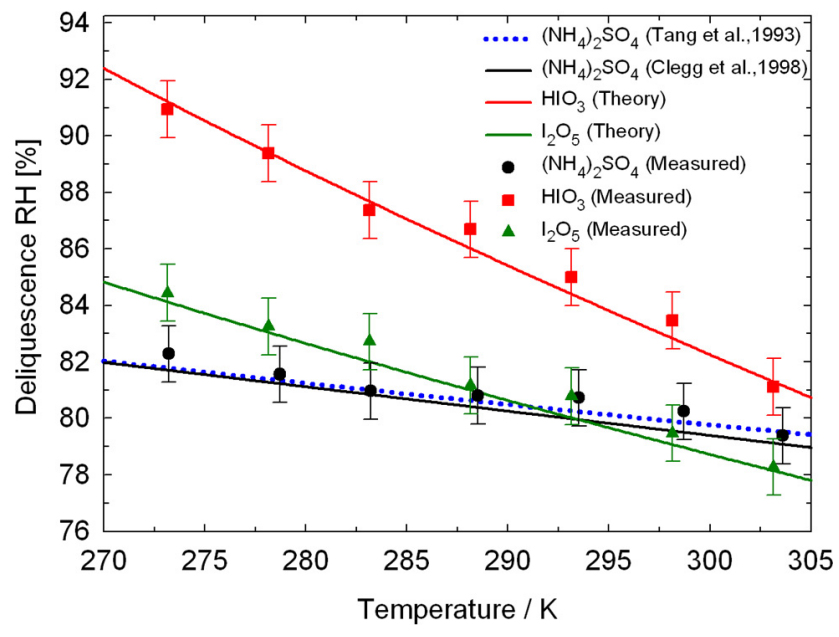

Fig. 9. Measured DRH for $\left(\mathrm{NH}_{4}\right)_{2} \mathrm{SO}_{4}, \mathrm{I}_{2} \mathrm{O}_{5}$, and $\mathrm{HIO}_{3}$ crystals as a function of temperature, and their corresponding theoretical fits calculated using equation 7 (see section 3.4). Estimated errors in the measured data are $\pm 1 \%(\mathrm{RH})$.

humidity or possibly serve as ice nuclei above ice saturation and below deliquescence.

\subsubsection{Efflorescence behaviour}

Freshly deliquesced droplets of both $\mathrm{HIO}_{3}$ and $\mathrm{I}_{2} \mathrm{O}_{5}$ on glass slides were subsequently exposed to decreasing $\mathrm{RH}$ values down to "dry" conditions $(<1 \% \mathrm{RH})$. Initially, $\mathrm{RH}$ was ramped down at intervals of $2 \%$ down to $60 \%$ and the droplets were left to equilibrate at each RH interval for 10 min. Then the RH was reduced in intervals of $10 \%$ to about $10 \%$, but leaving the droplets for $1 \mathrm{~h}$ at each interval. After this droplets were left for $2 \mathrm{~h}$ at $<1 \% \mathrm{RH}$ and then on the following day the same droplets were left at $<1 \% \mathrm{RH}$ for $7 \mathrm{~h}$. During these experiments, crystallisation was not observed.

Figure 11 shows a sequence of images for efflorescence experiments with $\left(\mathrm{NH}_{4}\right)_{2} \mathrm{SO}_{4}$, and iodate solutions made up with both $\mathrm{HIO}_{3}$ and $\mathrm{I}_{2} \mathrm{O}_{5}$. Efflorescence of the $\left(\mathrm{NH}_{4}\right)_{2} \mathrm{SO}_{4(a q)}$ droplets is clearly evident at $\mathrm{RH} \sim 32 \%$ whilst droplets of both $\mathrm{HIO}_{3}$ and $\mathrm{I}_{2} \mathrm{O}_{5}$ show no such behaviour down to the lowest RH levels which indicates that they remained non-crystalline.

This result is intriguing given that sub-saturated iodate solutions become increasingly viscous at higher concentrations. This trend is likely to continue as the iodate solutions become supersaturated as the RH is lowered below DRH. It is known that many aqueous solutions can become glassy at high concentration (Zobrist et al., 2008; Murray, 2008a; Murray and Bertram, 2008; Mikhailov et al., 2009; Murray et al., 2010c) and it was recently suggested that secondary organic aerosol can exist in a glassy state (Virtanen et al., 2010). This may have important implications for partitioning 


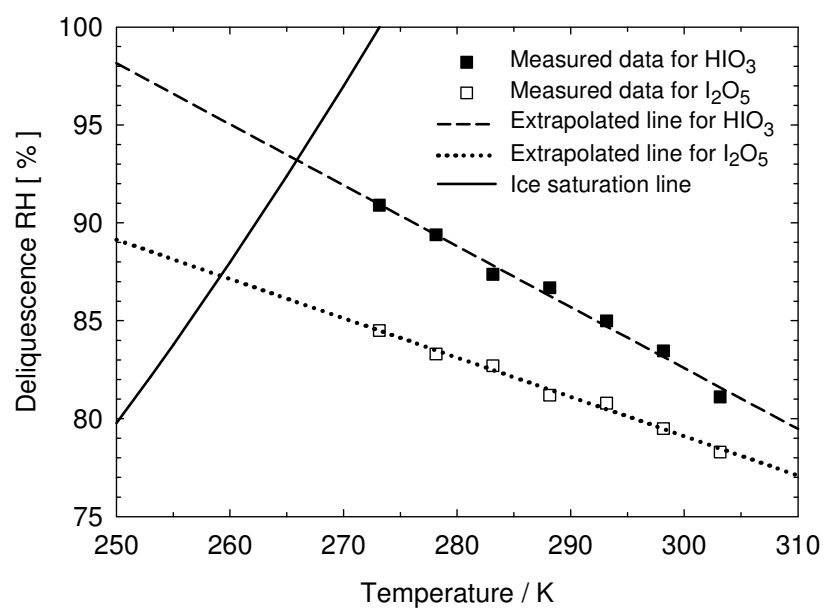

Fig. 10. Extrapolation of DRH fits of $\mathrm{HIO}_{3}$ and $\mathrm{I}_{2} \mathrm{O}_{5}$ to lower temperatures. The solid line is the ice saturation line while dashed and dotted lines indicate the extrapolation of DRH data of $\mathrm{HIO}_{3}$ and $\mathrm{I}_{2} \mathrm{O}_{5}$ respectively. The ice saturation line is determined from the ratio (multiplied by 100 to convert to $\%$ ) of $p_{\text {ice }}$ to $p_{\text {liq }}$ using the expressions (equations 7 and 10) given in Murphy and Koop (2005).

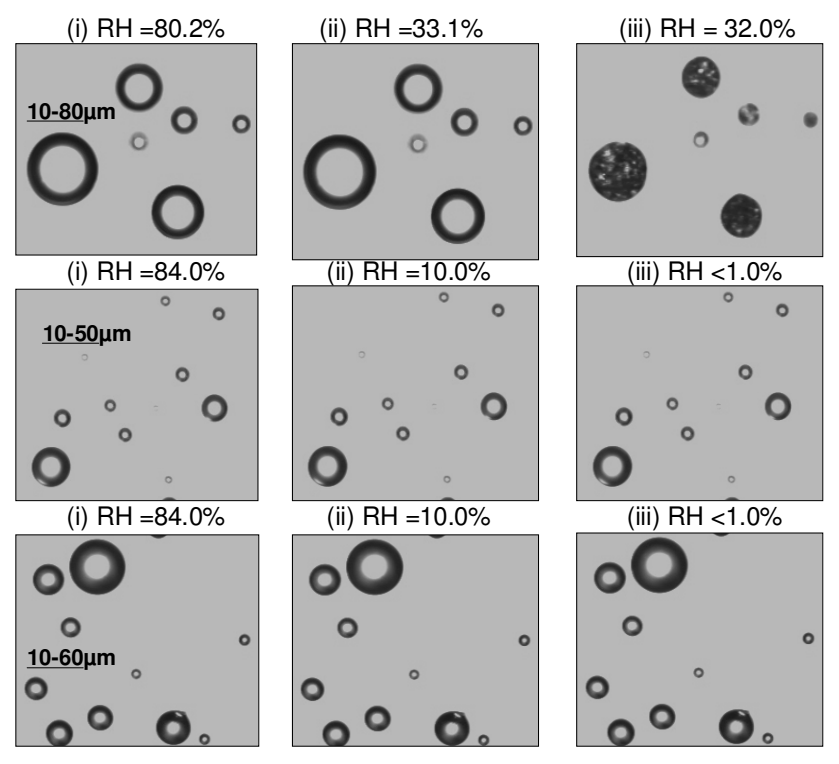

Fig. 11. A series of microscope images from the efflorescence experiments with droplets formed from crystals of $\left(\mathrm{NH}_{4}\right)_{2} \mathrm{SO}_{4}$ (top), $\mathrm{I}_{2} \mathrm{O}_{5}$ (middle), and $\mathrm{HIO}_{3}$ (bottom).

of semi-volatiles to the aerosol phase, heterogeneous reaction rates and may influence a particles' ability to act as a cloud condensation or ice nucleus. Further work is required to see if iodate solutions become glassy under atmospherically relevant conditions.

\section{Conclusions and atmospheric implications}

We report the first quantitative measurements of the molalitydependent water activity, solution density and viscosity for aqueous iodate solutions as well as the first measurements of the deliquescence humidity of crystalline $\mathrm{I}_{2} \mathrm{O}_{5}$ and $\mathrm{HIO}_{3}$. As discussed in the introduction, these compounds are likely to result from iodine-containing vapours released into the marine atmosphere. This physical data is crucial for evaluating the role of iodine oxide particles (IOPs) in the marine atmosphere.

In terms of the reported deliquescence properties, it should be noted that a number of studies of the hygroscopic behaviour of nanoparticles $(<20 \mathrm{~nm}$ diameter $)$ of inorganic salts indicate a distinct "size effect" with an increase in characteristic DRH level (above that for larger solid particles or bulk, crystalline samples) due to surface tension/forces resulting at such small particle sizes (Hameri et al., 2000, 2001; Russell and Ming, 2002; Biskos et al., 2006). The temperature-dependent values reported in our study therefore are likely to represent lower limits for deliquescence of crystalline IOPs in the marine atmosphere. Indeed, a recent laboratory study of the hygroscopic behaviour of freshly nucleated IOPs $(<10 \mathrm{~nm}$ in diameter $)$ reported no observable particle growth or evidence of deliquescence up to $\mathrm{RH}=90 \%$ (Saunders et al., 2010). In addition, the study of Väkevä et al. (2002) reported little hygroscopic growth of nucleation mode particles which were sampled during coastal particle 'bursts' at Mace Head, and subsequently exposed to $90 \% \mathrm{RH}$ in a hygroscopic tandem differential mobility analyser or $\mathrm{H}-$ TDMA. The study gives no indication of the composition of these particles, but it is now known that the most likely candidates for these daytime, low-tide events are IOPs. If local iodine source and particle growth rates are high enough e.g. at seaweed-rich coastal areas, it has been shown (Mahajan et al., 2010) that IOPs can grow rapidly enough to overcome scavenging by background (sea-salt) aerosol and grow to sizes $(>50 \mathrm{~nm})$ where deliquescence could take place at $80 \%<\mathrm{RH}<90 \%$.

As mentioned in the Introduction, the other known stable solid iodine oxide $\mathrm{I}_{2} \mathrm{O}_{4}$ has previously been reported as a likely composition for IOPs. However, this was based upon an observed lack of hygroscopic growth of particles formed in the laboratory (Jimenez et al., 2003), with $\mathrm{I}_{2} \mathrm{O}_{4}$ being known to be non-hygroscopic. However, observations from the studies of McFiggans et al. (2004) and Saunders et al. (2010) indicate that such a lack of particle growth in the presence of water vapour at high RH (as observed up to 90\%) is consistent with compact particles (less than $10 \mathrm{~nm}$ in diameter) of hygroscopic $\left(\mathrm{I}_{2} \mathrm{O}_{5}\right)$ composition which would not be expected to grow at $90 \% \mathrm{RH}$ or less as a consequence of the size effect described above. In addition, larger IOPs, which are non-compact or porous agglomerates (as observed in electron microscope imaging), exhibit a tendency to shrink as a result of water uptake. 
Our studies of iodate solution droplets at low humidity indicate that they do not effloresce even when left at below $1 \% \mathrm{RH}$ for many hours. This observation suggests that deliquesced IOPs (formed in humid environments) will remain in a non-crystalline metastable aqueous state. This may have implications for the uptake of other volatile chemical species and the subsequent growth rates of IOPs. Our viscosity measurements indicate that these iodate solution droplets become increasingly viscous at lower temperatures and higher concentrations, which raises the possibility that they may become glassy under atmospherically relevant conditions. Future studies should focus on the properties of metastable supersaturated iodate solutions and their apparent inability to crystallise.

Acknowledgements. The authors would like to thank G. McFiggans and A. Murray Booth (School of Earth, Atmospheric and Environmental Sciences, University of Manchester) for use of and assistance with the activity meter. This study was supported by the UK Natural Environment Research Council (NERC, NE/E005659/1 and NE/D009308/1) and the European Research Council (ERC, 240449 - ICE). RK is grateful to the Indian Government for PhD funding, and Multanimal Modi (Postgraduate) College, Modinagar (U.P.), India for granting study leave. ASM is grateful to the School of Chemistry for $\mathrm{PhD}$ funding.

Edited by: R. Volkamer

\section{References}

Angell, C. A.: Liquid fragility and the glass transition in water and aqueous solutions, Chem. Rev., 102, 2627-2650, 2002.

Biskos, G., Paulsen, D., Russell, L. M., Buseck, P. R., and Martin, S. T.: Prompt deliquescence and efflorescence of aerosol nanoparticles, Atmos. Chem. Phys., 6, 4633-4642, doi:10.5194/acp-64633-2006, 2006.

Burkholder, J. B., Curtius, J., Ravishankara, A. R., and Lovejoy, E. R.: Laboratory studies of the homogeneous nucleation of iodine oxides, Atmos. Chem. Phys., 4, 19-34, doi:10.5194/acp-4-192004, 2004.

Caurie, M.: Raoult's law, water activity and moisture availability in solutions, J. Food Sci., 48, 648-649, 1983.

Clegg, S. L., Brimblecombe, P., and Wexler, A. S.: Thermodynamic model of the system $\mathrm{H}^{+}-\mathrm{NH}_{4}^{+}-\mathrm{SO}_{4}^{2-}-\mathrm{NO}_{3}^{-}-\mathrm{H}_{2} \mathrm{O}$ at tropospheric temperatures, J. Phys. Chem. A, 102, 2137-2154, 1998.

Daehlie, G. and Kjekshus, A.: Iodine oxides: Part I. On $\mathrm{I}_{2} \mathrm{O}_{3} \cdot \mathrm{SO}_{3}$, $\mathrm{I}_{2} \mathrm{O}_{3} \cdot 4 \mathrm{SO}_{3} \cdot \mathrm{H}_{2} \mathrm{O}, \mathrm{I}_{2} \mathrm{O}_{3} \cdot \mathrm{SeO}_{3}$ and $\mathrm{I}_{2} \mathrm{O}_{4}$, Acta Chem. Scand., 18, 144-156, 1964.

Dymarska, M., Murray, B. J., Sun, L. M., Eastwood, M. L., Knopf, D. A., and Bertram, A. K.: Deposition ice nucleation on soot at temperatures relevant for the lower troposphere, J. Geophys. Res., 111, D04204, doi:10.1029/2005JD006627, 2006.

Eastwood, M. L., Cremel, S., Wheeler, M., Murray, B. J., Girard, E., and Bertram, A. K.: The effects of sulfuric acid and ammonium sulfate coatings on the ice nucleation properties of kaolinite particles, Geophys. Res. Lett., 36, L02811, doi:02810.01029/02008GL035997, 2009.
Gilfedder, B. S., Lai, S. C., Petri, M., Beister, H., and Hoffmann, T.: Iodine speciation in rain, snow and aerosols, Atmos. Chem. Phys., 8, 6069-6084, 2008, http://www.atmos-chem-phys.net/8/6069/2008/.

Goldman, S., Bates, R. G., and Robinson, R. A.: Osmotic coefficients and activity coefficients of iodic acid at high concentrations, J. Sol. Chem., 3, 593-602, 1974.

Groschuff, E.: On iodic acid, Z. Anorg. Chem., 47, 331-352, 1905.

Hameri, K., Vakeva, M., Hansson, H. C., and Laaksonen, A.: Hygroscopic growth of ultrafine ammonium sulphate aerosol measured using an ultrafine tandem differential mobility analyzer, J. Geophys. Res., 105, 22231-22242, 2000.

Hameri, K., Laaksonen, A., Vakeva, M., and Suni, T.: Hygroscopic growth of ultrafine sodium chloride particles, J. Geophys. Res. 106, 20749-20757, 2001.

Jimenez, J. L., Bahreini, R., Cocker III, D. R., Zhuang, H., Varutbangkul, V., Flagan, R. C., Seinfeld, J. H., O’Dowd, C. D. and Hoffmann, T.: New particle formation from photooxidation of diiodomethane $\left(\mathrm{CH}_{2} \mathrm{I}_{2}\right)$, J. Geophys. Res., 108, 4318, doi:10.1029/2002JD002452, 2003.

Kitic, D., Jardim, D. C. P., Favetto, G. J., Resnik, S. L., and Chirife, J.: Theoretical prediction of water activity of standard saturated salt-solutions at various temperatures, J. Food Sci., 51, 10371041, 1986.

Koop, T.: Homogeneous ice nucleation in water and aqueous solutions, Z. Phys. Chem., 218, 1231-1258, 2004.

Korson, L., Drost-Hansen, W., and Millero, F.J.: Viscosity of water at various temperatures, J. Phys. Chem., 73, 34-39, 1969.

Lide, D. R.: CRC Handbook of Chemistry and Physics, 90th Ed., CRC, Boca Raton, USA, 67-114, 2009.

McFiggans, G., Coe, H., Burgess, R., Allan, J., Cubison, M., Alfarra, M. R., Saunders, R., Saiz-Lopez, A., Plane, J. M. C., Wevill, D., Carpenter, L., Rickard, A. R., and Monks, P. S.: Direct evidence for coastal iodine particles from Laminaria macroalgae - linkage to emissions of molecular iodine, Atmos. Chem. Phys., 4, 701-713, doi:10.5194/acp-4-701-2004, 2004.

McFiggans, G., Artaxo, P., Baltensperger, U., Coe, H., Facchini, M. C., Feingold, G., Fuzzi, S., Gysel, M., Laaksonen, A., Lohmann, U., Mentel, T. F., Murphy, D. M., O’Dowd, C. D., Snider, J. R., and Weingartner, E.: The effect of physical and chemical aerosol properties on warm cloud droplet activation, Atmos. Chem. Phys., 6, 2593-2649, doi:10.5194/acp-6-2593-2006, 2006.

McFiggans, G., Bale, C. S. E., Ball, S. M., Beames, J. M., Bloss, W. J., Carpenter, L. J., Dorsey, J., Dunk, R., Flynn, M. J., Furneaux, K. L., Gallagher, M. W., Heard, D. E., Hollingsworth, A. M., Hornsby, K., Ingham, T., Jones, C. E., Jones, R. L., Kramer, L.J., Langridge, J. M., Leblanc, C., LeCrane, J.-P., Lee, J. D., Leigh, R. J., Longley, I., Mahajan, A. S., Monks, P. S., Oetjen, H., Orr-Ewing, A. J., Plane, J. M. C., Potin, P., Shillings, A. J. L., Thomas, F., von Glasow, R., Wada, R., Whalley, L. K., and Whitehead, J. D.: Iodine-mediated coastal particle formation: an overview of the Reactive Halogens in the Marine Boundary Layer (RHaMBLE) Roscoff coastal study, Atmos. Chem. Phys., 10, 2975-2999, doi:10.5194/acp-10-2975-2010, 2010.

Mahajan, A. S., Plane, J. M. C., Oetjen, H., Mendes, L., Saunders, R. W., Saiz-Lopez, A., Jones, C. E., Carpenter, L. J., and McFiggans, G. B.: Measurement and modelling of tropospheric reactive halogen species over the tropical Atlantic Ocean, At- 
mos. Chem. Phys., 10, 4611-4624, doi:10.5194/acp-10-46112010, 2010.

Martin, S.: Phase transitions of aqueous atmospheric particles, Chem. Rev., 100, 3403-3453, 2000.

Mikhailov, E., Vlasenko, S., Martin, S. T., Koop, T., and Pöschl, U.: Amorphous and crystalline aerosol particles interacting with water vapor: Conceptual framework and experimental evidence for restructuring, phase transitions and kinetic limitations, Atmos. Chem. Phys., 9, 9491-9522, doi:10.5194/acp-9-9491-2009, 2009.

Murphy, D. M. and Koop, T.: Review of the vapour pressures of ice and supercooled water for atmospheric applications, Q. J. Roy. Meteorol. Soc., 131, 1539-1565, 2005.

Murray, B. J.: Inhibition of ice crystallisation in highly viscous aqueous organic acid droplets, Atmos. Chem. Phys., 8, 54235433, doi:10.5194/acp-8-5423-2008, 2008a.

Murray, B. J.: Enhanced formation of cubic ice in aqueous organic acid droplets, Env. Res. Lett., 3, 025008, doi:10.1088/17489326/3/2/025008, 2008b.

Murray, B. J. and Bertram, A. K.: Inhibition of solute crystallisation in aqueous $\mathrm{H}^{+}-\mathrm{NH}_{4}^{+}-\mathrm{SO}_{4}^{2-}-\mathrm{H}_{2} \mathrm{O}$ droplets, Phys. Chem. Chem. Phys., 10, 3287-3301, 2008.

Murray, B. J., Broadley, S. L., Wilson, T. W., Bull, S., Wills, R. H., Christenson, H. K., and Murray, E. J.: Kinetics of the homogeneous freezing of water, Phys. Chem. Chem. Phys., 12, 1038010387, 2010a.

Murray, B. J., Wilson, T. W., Broadley, S. L., and Wills, R. H.: Heterogeneous freezing of water droplets containing kaolinite and montmorillonite particles, Atmos. Chem. Phys. Discuss., 10, 9695-9729, doi:10.5194/acpd-10-9695-2010, 2010b.

Murray, B. J., Wilson, T. W., Dobbie, S., Cui, Z. Q., Al-Jumur, S., Mohler, O., Schnaiter, M., Wagner, R., Benz, S., Niemand, M., Saathoff, H., Ebert, V., Wagner, S., and Karcher, B.: Heterogeneous nucleation of ice particles on glassy aerosols under cirrus conditions, Nat. Geosci., 3, 233-237, 2010c.

Nayar, M. R., Srivastava, L. N., Sen, A. B., Gopal, R., and Sharma, P. N.: The constitution of iodic acid. III, Z. Anorg. Allg. Chem., 240, 217-231, 1939.

O'Dowd, C. D. and De Leeuw, G.: Marine aerosol production: A review of the current knowledge, Philos. Trans. R. Soc. London, Ser. A, 365, 1753-1774, 2007.

O’Dowd, C. D., Hämeri, K., Mäkelä, J. M., Pirjola, L., Kulmala, M., Gerard Jennings, S., Berresheim, H., Hanson, H.-C., de Leeuw, G., Kunz, G. J., Allen, A. G., Nicholas Hewitt, C., Jackson, A., Viisanen, Y., and Hoffmann, T.: A dedicated study of new particle formation and fate in the coastal environment (PARFORCE): Overview of objectives and achievements, J. Geophys. Res., 107, 8108, doi:10.1029/2001JD000555, 2002a.

O’Dowd, C. D., Jimenez, J. L., Bahreini, R., Flagan, R. C., Seinfeld, J. H., Hämeri, K., Pirjola, L., Kulmala, M., Gerard Jennings, S., and Hoffmann, T.: Marine aerosol formation from biogenic iodine emissions, Nature, 417, 632-636, 2002b.

Onasch, T. B., Siefert, R. L., Brooks, S. D., Prenni, A. J., Murray, B., Wilson, M. A., and Tolbert, M. A.: Infrared spectroscopic study of the deliquescence and efflorescence of ammonium sulfate aerosol as a function of temperature, J. Geophys. Res., 104, 21317-21326, 1999.
Pechtl, S., Schmitz, G., and von Glasow, R.: Modelling iodideiodate speciation in atmospheric aerosol: Contributions of inorganic and organic iodine chemistry, Atmos. Chem. Phys., 7, 1381-1393, doi:10.5194/acp-7-1381-2007, 2007.

Pethybridge, A. D. and Prue, J. E.: Equilibria in aqueous solutions of iodic acid, Trans. Faraday Soc., 63, 2019-2033, 1967.

Rogers, M. T. and Helmholz, L.: The crystal structure of iodic acid, J. Am. Chem. Soc., 63, 278-284, 1941.

Russell, L. M. and Ming, Y.: Deliquescence of small particles, J. Chem. Phys., 116, 311-321, 2002.

Saiz-Lopez, A., Mahajan, A. S., Salmon, R. A., Bauguitte, S. J. B., Jones, A. E., Roscoe, H. K., and Plane, J. M. C.: Boundary layer halogens in coastal Antarctica, Science, 317, 348-351, 2007.

Saunders, R. W. and Plane, J. M. C.: Formation pathways and composition of iodine oxide ultra-fine particles, Environ. Chem., 2, 299-303, 2005.

Saunders, R. W., Kumar, R., Mahajan, A. S., Murray, B. J., and Plane, J. M. C.: Studies of the formation and growth of aerosol from molecular iodine precursor, Z. Phys. Chem., 224, 10951117, 2010.

Segur, J. B. and Oberstar, H. E.: Viscosity of glycerol and its aqueous solutions, Ind. Eng. Chem., 43, 2117-2120, 1951.

Seinfeld, J. H. and Pandis, S. N.: Atmospheric Chemistry and Physics: From air pollution to climate change, 2nd Ed., Wiley \& Sons, Hoboken, NJ, USA, 2006.

Selte, K. and Kjekshus, A.: Iodine oxides: Part III. The crystal structure of $\mathrm{I}_{2} \mathrm{O}_{5}$, Acta Chem. Scand., 24, 1912-1924, 1970.

Sereno, A. M., Hubinger, M. D., Comesana, J. F., and Correa, A.: Prediction of water activity of osmotic solutions, J. Food Eng., 49, 103-114, 2001.

Stoloff, L.: Calibration of water activity measuring instruments and devices: Collaborative study, J. Assoc. Off. Anal. Chem., 61, 1166-1178, 1978.

Strong, L. E., and Pethybridge, A. D.: Aqueous iodic acid - conductance and thermodynamics, J. Sol. Chem., 16, 841-855, 1987.

Tang, I. N. and Munkelwitz, H. R.: Composition and temperaturedependence of the deliquescence properties of hygroscopic aerosols, Atmos. Environ., 27, 467-473, 1993.

Topping, D. O., McFiggans, G. B., and Coe, H.: A curved multicomponent aerosol hygroscopicity model framework: Part 1 inorganic compounds, Atmos. Chem. Phys., 5, 1205-1222, 2005 , http://www.atmos-chem-phys.net/5/1205/2005/.

Väkevä, M., Hämeri, K., and Aalto, P. P.: Hygroscopic properties of nucleation mode and Aitken mode particles during nucleation bursts and in background air on the west coast of Ireland, J. Geophys. Res., 107, 814, doi:10.1029/2000JD000176, 2002.

Virtanen, A., Joutsensaari, J., Koop, T., Kannosto, J., Yli-Pirilä, P., Leskinen, J., Mäkelä, J. M., Holopainen, J. K., Pöschl, U., Kulmala, M., Worsnop, D. R., and Laaksonen, A.: An amorphous solid state of biogenic secondary organic aerosol particles, Nature, 467, 824-827, 2010.

Wexler, A. S., and Clegg, S. L.: Atmospheric aerosol models for systems including the ions $\mathrm{H}^{+}, \mathrm{NH}_{4}^{+}, \mathrm{Na}^{+}, \mathrm{SO}_{4}^{2-}, \mathrm{NO}_{3}^{-}, \mathrm{Cl}^{-}$, $\mathrm{Br}^{-}$, and $\mathrm{H}_{2} \mathrm{O}$, J. Geophys. Res., 107, 2002.

Zobrist, B., Marcolli, C., Pedernera, D. A., and Koop, T.: Do atmospheric aerosols form glasses?, Atmos. Chem. Phys., 8, 52215244, doi:10.5194/acp-8-5221-2008, 2008. 